\title{
How expensive is an energy transition? A lesson from the German Energiewende
}

\author{
Thomas Unnerstall(B)
}

\begin{abstract}
The Paris climate agreement of December 2015 is generally considered a breakthrough on the way to a sustainable future for mankind. In particular, the agreement calls for fundamental transitions in the energy systems worldwide, since more than $80 \%$ of CO2 emissions stem from the use of fossil fuels in the energy supply. Considering such energy transitions, in any country there will certainly be technical issues, there will be debates as to which political instruments are most suitable, and others; but there is no doubt that the question of cost is one of the most crucial issues in the course of such a long-term project. After all, the expected financial burden on the national economy and its stakeholders is the most convincing argument for putting in energy transition off or for slowing it down. There is also no doubt that the German Energiewende, at first sight, does not serve as an encouraging example in this respect: The cost bill - in the sense of the direct, perceptible financial effects - has already run up to almost $€$ 500 billion, and the German private households as well as many businesses pay significantly more for electricity than in most other OECD-countries. As a consequence, in Germany there is a growing opposition against going forward with the Energiewende as planned, and also in the international media, the initially positive image of the German project has suffered.

A closer look at the costs of the German energy transition, however, reveals that around $75 \%$ of them are due to two particularities of the Energiewende that do not hold true for other energy transitions: the politically enforced nuclear phase-out and the fact that Germany massively expanded renewable energies at a time when they were still very expensive.

Therefore, the real lesson of the German example is the opposite of what it may seem: The transition to renewable energies in the electricity sector in a highly industrialized country can be quite affordable.
\end{abstract}

\section{Background}

Ever since its official launch in 2010/2011, the German Energiewende has received worldwide attention. At first, international comments were mostly positive, sometimes even full of admiration, due to its-at least at the time-very ambitious goals for reducing $\mathrm{CO} 2$ and for expanding renewable energies, notably in electricity generation. Nowadays, many observers from abroad have become more skeptical; and the reason is not that unforeseen technical difficulties have emerged in the course of the project so far; the reason is that the costs are perceived to have gotten out of hand. "Other countries simply cannot afford an energy transition" is a conclusion that suggests itself, and thus the German

Correspondence: tunner@online.de

Stockstadt, Germany

Springer Open example-even though a frontrunner and meant to inspire others-actually risks to have an adverse effect.

In the debate within Germany, too, the question of the cost of the Energiewende and the ensuing burden on private households and especially on businesses is the most controversial and the most crucial issue [1,2]. Indeed, the initial broad consensus between all major political parties on the main Energiewende goals and principles seems to crumble.

Just recently, several studies of the estimated costs of the Energiewende until 2025/2030 have been published [3-5], and despite a number of methodological differences they arrive at comparable figures. The Energiewende in the electricity sector alone-i.e., not yet taking into account the necessary transformation of the heating and transportation sectors-up to 2030 is expected to require financial support for renewable energies, costs for grid expansion, etc. on the order of $€ 600-700$ billion 
[5]. It is true that these costs are spread out over a period of 50 years (2000-2050); but the cost after 2030 on the route to an almost completely decarbonized electricity system envisaged for 2050 or 2060 cannot even be prognosticated yet.

In any case, such figures could certainly have a deterring effect in view of other energy transitions-energy transitions that are or at least should be on the political agenda of many countries in the wake of the Paris climate agreement of 2015 .

The aim of this article is to show that this need not be the case: correctly analyzed, the German example can actually inspire optimism with respect to the affordability of energy transitions in comparable countries, at least with respect to the electricity sector.

The argument will proceed in three steps:

- We define two stages of the Energiewende up to 2030 and estimate the costs incurred during these two phases

- We identify nuclear phase-out and early action as distinctive features of the German Energiewende

- We roughly estimate the cost of a (fictitious) transition of Germany's electricity sector without nuclear phase-out and without early action.

Before getting started, however, it is important to briefly outline the methodology of this article, to delineate its scope and to define the principal terms used.

\section{Methodology}

We will use the term "cost" to mean the direct financial effects of the Energiewende: in particular, the so-called "differential costs" due to the expansion of renewable energies (RE) explained below, costs for grid expansion, government funding for energy efficiency investments such as CHP plants, government funding for R\&D, and the so-called "merit order effect."

This is certainly quite a narrow view on the cost issue-we do neglect secondary cost effects (effects on jobs, taxes etc.), and we do neglect the so-called external costs of power production (such as cost of environmental damages).

Taking such a narrow view, however, seems justified for our purposes since the direct costs are the ones immediately noticeable and quantifiable. Thus, the public and political debates often focus solely on these costs.

By far the most important direct cost factor are the so-called differential costs for the expansion of RE: the remuneration/feed-in-tariff to the investors of the REplants for the electricity produced (granted by the German Renewable Energies Act (GREA) for the first 20 years of operation) minus the market value of this electricity. These differential costs have to be paid via the GREA- surcharge by the electricity customers. For each RE plant, the differential costs can be calculated as 20 years $\times$ feed-in-tariff $\times$ average electricity production per year-average market value of the electricity produced over these 20 years.

We will assume here that the average market value will turn out to be $3 \mathrm{ct} / \mathrm{kWh}$ over the time periods in question, which roughly corresponds to the average market value over the past few years. Of course, this is a somewhat bold assumption-but it is relatively easy to see that the arguments to be developed in the following sections do not depend on this figure. In other words, assuming, e.g., 2.5 or $4 \mathrm{ct} / \mathrm{kWh}$ or a certain development over time does not alter our main conclusions (at least in all reasonable scenarios).

It can be shown $[3,5]$ that the other direct cost factors enumerated above-grid expansion, funding for CHP and for R\&D-are much lower than the differential cost of the RE expansion itself, and they are being at least partly offset by the positive merit order effect. Taken together, these factors amount to no more than $10 \%$ of the differential costs.

Finally, we must assume here that the original targets for the Energiewende in the electricity sector up to 2030 remain unchanged: no nuclear power, 50\% renewables in the electricity mix, but no further heavy political intervention in the power market. (There is certainly a debate in Germany about significantly accelerating the transition speed in order to better meet the overall CO2-reduction goals: phasing out coal until $2030,60 \%$ renewables or more in 2030 , massive subsidies for power-to-gas and storage technologies, etc. If such measures should become reality, the cost estimates given here are no longer valid).

Summing up, the differential costs-the immediate financial burden on households and businesses due to the expansion of RE power plants-give to a certain extent an estimate of the (direct) costs of the Energiewende in the electricity sector which is admittedly very limited in scope and quite rough, but which is sufficient for our purposes. Differential costs do not reflect the real costs of the RE expansion in a strictly scientific sense; but our aim here is not to give a comprehensive scientific account of the cost issue, but to address in an easily understandable way important trends in the public and political discussion on the cost issue.

\section{Two stages of the Energiewende up to $\mathbf{2 0 3 0}$}

With respect to the costs as just defined, the German Energiewende in the electricity sector until 2030 can be divided up into two stages:

Stage 1: 2000 to 2016

Stage 2: 2017 to 2030 
In stage 1, renewable energy (RE) plants of around $100 \mathrm{GW}$ were built which produce on average approx. $170 \mathrm{TWh}$ per year of electricity. The average cost of this electricity - the remunerations granted by the GREA-is approximately $16 \mathrm{ct} / \mathrm{kWh}$ for 20 years [6], while the current market value is only around $3 \mathrm{ct} / \mathrm{kWh}^{2}$ Assuming this to be the average market value for the time periods in question, the net cost to the German national economy-paid via the GREA apportionment (EEG-Umlage; $6.9 \mathrm{ct} / \mathrm{kWh}$ in 2017) by the electricity consumers-can thus be estimated to be approx. $13 \mathbf{~ c t} / \mathbf{k W h}$. It follows that the total costs of this previous RE expansion are probably on the order of $€ 450$ billion ( $13 \mathrm{ct} / \mathrm{kWh} \times 170 \mathrm{TWh} \times 20$ years).

In stage 2, the task is-with respect to the electricity sector alone, i.e., not taking into account the socalled sector coupling-to achieve the milestone in 2030 of an approx. 50\% share of RE in electricity generation, which translates to an RE electricity production of 280-300 TWh. Since it can be estimated that 50-70 TWh/a of RE electricity from plants built in stage 1 will go out of the system by 2030 (due to end of technical lifetime or to insufficient economic viability without the GREA remunerations), it will be necessary to build RE plants with an average electrical production of 140-160 TWh/a.

The latest auction results in Germany for PV, for offshore wind farms and for onshore wind parks suggest that the necessary remunerations to the investors for this electricity will not exceed $6-7 \mathrm{ct} / \mathrm{kWh}-$ far below anything that was expected only 2 or 3 years ago. And they might still be considerably lower due to further cost degressions to be expected on the way to 2030. But even not taking this into account, and again assuming an average market value of only $3 \mathrm{ct} / \mathrm{kWh}$ (many experts expect rising prices on the electricity exchange EEX in the next decade), the net cost can be estimated to be 3-4 ct/kWh. The total cost, then, of the expansion of $\mathrm{RE}$ in the second stage can be estimated to be in the range of $€ 90-130$ billion $(3-4 \quad \mathrm{ct} / \mathrm{kWh} \times 140-$ $160 \mathrm{TWh} \times 20$ years).

Taken together and considering smaller cost effects (see "Methodology" section), stages 1 and 2 will probably amount to a cost balance of between $€ 600$ and 700 billion. It is obvious here that roughly $75 \%$ of these costs accrued in stage 1 . The main reasons are clear: up until 2010, especially PV electricity was extremely expensive (Table 1),

Table 1 Average GREA-subsidies for PV-systems in Germany, 2000-2018 (in € ct/kWh)

\begin{tabular}{lllll}
\hline 2000 & 2005 & 2010 & 2015 & $2018^{a}$ \\
\hline 51 & 53 & 35 & 11 & $9-10$ \\
\hline $\begin{array}{l}\text { [7, 8] } \\
\text { ancluding auction result from February 2017; own calculations }\end{array}$
\end{tabular}

and in general, the massive expansion of RE first in Germany and then in many other countries has led to drastic cost degressions of PV and Wind in the last years.

\section{Nuclear phase-out and early action as distinctive features}

No matter the future of energy policies around the globe, there is little doubt that the German Energiewende is and will remain unique in two respects:

- Despite ambitious climate goals, Germany decided to phase-out the $\mathrm{CO} 2$-free nuclear energy until 2022. Obviously, this decision-which is still unparalleled in any other country with nuclear power plants-renders it much harder and more expensive to achieve $\mathrm{CO} 2$ reduction goals ${ }^{3}$

- Germany was the first country to massively expand RE for electricity generation. This "early action" certainly has had its merits, but-as just shown-it is also responsible for much of the substantial Energiewende bill up to now.

Put another way: because of these two unique features heavily influencing the financial aspects, no inference whatsoever can be made from the cost of the Energiewende to the cost of energy transitions in other countries. Consequently, the German figures should have no deterring effect at all-they simply do not give a clue as to what an energy transition might cost in a comparable country.

\section{Cost of a transition of Germany's electricity sector without (rapid) nuclear phase-out and without early action}

We can take the same point further and consider a transition scenario for Germany's electricity system without these two distinct characteristics of the Energiewende: a scenario where Germany-with the same $\mathrm{CO} 2$ reduction goals in electricity generation-continues to operate its newer nuclear power plants (i.e., those built after 1980) beyond 2030, and where the expansion of RE is launched only in 2017.

What would such a transition cost (until 2030)?

The starting point for this fictitious energy transition would be the electricity generation mix, had the Energiewende between 2000 and 2016 not happened ${ }^{4}$; presumably, it would look something like this ${ }^{5}$ :

Nuclear energy 160 TWh.

Renewable energies $30 \mathrm{TWh}$.

Fossil fuels $\quad 425 \mathrm{TWh}$.

Total $\quad 615 \mathrm{TWh}$ 
The target state in 2030 would be defined by a $50 \%$ share of $\mathrm{CO} 2$-free energies as well as by a substantial advance in energy efficiency. Taking the same rate of decrease in electricity consumption in the years 2017 to 2030 as has actually happened in the real Energiewende between 2010 and 2016, we assume a domestic demand of approximately $570 \mathrm{TWh}$ in 2030. The target electricity mix in 2030 then looks like this:

$\begin{array}{ll}\text { Nuclear energy } & 100 \mathrm{TWh} \\ \text { Renewable energies } & 190 \mathrm{TWh} \\ \text { Fossil fuels } & 280 \mathrm{TWh} \\ \text { Total } & \mathbf{5 7 0} \mathbf{~ T W h}\end{array}$

Consequently, the transformation in this scenario consists of expanding RE by around 160 TWh between 2017 and 2030. We further assume that the new GREA to be introduced in 2017 is basically similar to the actual GREA in place-it works with the tender model, it grants fixed remunerations for 20 years, and it provides around $15 \mathrm{GW}$ of offshore wind, $40 \mathrm{GW}$ of onshore wind, and $30 \mathrm{GW}$ of PV (only open space systems).

As seen in the "Two stages of the Energiewende up to 2030" section, the upper limit for the cost of this RE expansion can be estimated to be only $3-4 \mathrm{ct} / \mathrm{kWh}$ (net); the total cost would thus probably not exceed $(3-4 \mathrm{ct} / \mathrm{kWh} \times$ $160 \mathrm{TWh} \times 20$ years $=) € 100-120$ billion, to be paid in the years 2018 to 2050 .

In this scenario, until 2030 only moderate grid expansion will be needed ${ }^{6}$ - the amount of RE electricity in 2030 (190 TWh) equals the actual RE production in Germany of 2016, which has been integrated into the existing electricity system with only limited extra measures (switching off RE-plants, redispatching conventional power plants); these costs would in all probability be offset by the positive effect of lower EEX prices. Taking into account costs to enhance electricity efficiency, the total cost of such a transition of Germany's electricity system up to 2030 can be estimated not to exceed $€ 150$ billion, ${ }^{7}$ or on average less than $€ 5$ billion per year (2018-2050).

In terms of GDP-assuming moderate real growth of $1 \%$ and not even taking into account inflation-, this corresponds to an annual average of less than $0.15 \%$ of GDP.

Let us discuss this result with a few comparative figures:

- The GREA apportionment would not exceed $2 \mathrm{ct} / \mathrm{kWh}$ (compared to a maximum of approx. $8 \mathrm{ct} / \mathrm{kWh}$ in the actual Energiewende, expected for around 2023).

- The burden on private households would thus not exceed approximately $€ 5$ per month (2017 prices); on average, it would amount to only roughly $0.1 \%$ of future consumption spending (whereas, e.g., alcoholic beverages and tobacco products each amount to more than $1 \%$ of consumption spending).
- The average "electricity transition bill" to German businesses would equally be less than $0.1 \%$ of sales volumes in the future.

- The subsidies for hard-coal mining in Germany between 1970 and 2010 amounted to around 280 billion, equating to an annual average of more than $0.3 \%$ of GDP.

In other words, this fictitious transition of Germany's electricity system-up to a $50 \%$ decarbonization by 2030 - could be considered as a feasible challenge to the German national economy and as quite affordable for its main stakeholders.

\section{Conclusion}

Contrary to first sight, the experience of Germany with its Energiewende does not show that any energy transition in an industrialized country is an expensive undertaking and is bound to place a heavy financial burden on private households and impair the competitiveness of its businesses. Indeed, the cost figures often cited in this context are decisively influenced by unique features of the German energy transition that do not hold true for other countries.

Actually, the true message is the opposite one: at least in Germany, the transformation of the electricity system with a goal of $50 \%$ decarbonization by 2030 , launched today and without nuclear phase-out, would not be expensive at all. While this result, of course, cannot be translated to other countries as such, it should nevertheless be encouraging to all those around the globe who work for energy transitions in their countries.

\section{Endnotes}

${ }^{1}$ With "merit order effect" we denote the fact that the prices on the German energy exchange are lower (by around $€ 10-15 / \mathrm{MWh}$ ) due to the Energiewende since the most expensive power plants are being ousted by the $\mathrm{RE}$ (with variable costs close to 0 ). This effect lowers the electricity bill for the customers.

${ }^{2}$ All prices will be given in Euro-cent per kilowatt hour $=\mathrm{ct} / \mathrm{kWh}$.

${ }^{3}$ This is true for the direct costs which are the focus of this article; we do not take into account external costs here ("Methodology" section).

${ }^{4} \mathrm{We}$ will assume in the following that even without the Energiewende, the cost degression of RE would have taken place, knowing that, in fact, it has played an important role in this.

${ }^{5}$ We do not take into account here possible electricity exports.

${ }^{6} \mathrm{New}$ power lines would be necessary mostly to connect the offshore windfarms to the grid and to transport part of the wind electricity down south. 
${ }^{7}$ This holds all the more true since without the transition envisaged here, a few conventional power plants might have to be replaced until 2030 .

\section{Acknowledgements}

I am grateful to many colleagues for discussions on the German Energiewende which have helped me to enhance my knowledge and to balance my views, in particular to Prof. Peter Birkner, Dr. Christoph Müller, and Jörg Stäglich.

\section{Consent for publication}

Not applicable

\section{Competing interests}

The author declares that he has no competing interests.

Received: 19 June 2017 Accepted: 29 November 2017

Published online: 18 December 2017

\section{References}

1. Handelsblatt 2017. Strompreise geraten ausser Kontrolle http://www. handelsblatt.com/unternehmen/energie/kosten-fuer-energiewendestrompreise-geraten-ausser-kontrolle/14667630.html. Accessed 13 Sept 2017

2. Welt 2016. Die Energiewende droht zum ökonomischen Desaster zu werden https:/www.welt.de/wirtschaft/article162600538/Die-Energiewende-drohtzum-oekonomischen-Desaster-zu-werden.html. Accessed 13 Sept 2017

3. DICE Consult 2016. Kosten der Energiewende-Untersuchung der Energiewendekosten im Bereich der Stromerzeugung in den Jahren 2000-2015 in Deutschland http://www.insm.de/insm/dms/insm/text/soziale-marktwirtschaft/ EEG/INSM_Gutachten_Energiewende.pdf. Accessed 13 Sept 2017

4. Fraunhofer ISE 2015. Was kostet die Energiewende? https://www.ise. fraunhofer.de/de/veroeffentlichungen/studien/was-kostet-die-energiewende. html. Accessed 13 Sept 2017

5. Unnerstall, T. 2017. The German energy transition-concept, implementation, cost and lessons. Springer May 2017

6. Netztransparenz 2016. Prognose der EEG-Umlage 2017 nach AusglMechV https://www.netztransparenz.de/portals/1/Content/EEG-Umlage/EEGUmlage\%202017/20161014_Veroeffentlichung_EEG-Umlage_2017.pdf. Accessed 13 Sept 2017

7. BDEW 2015. Erneuerbare Energien und das EEG (2015) https://www.bdew. de/internet.nsf/id/20150511-o-energie-info-erneuerbare-energien-und-daseeg-zahlen-fakten-grafiken-2015-de/\$file/Energie-Info_Erneuerbare_ Energien_und_das_EEG_2015_11.05.2015_final.pdf. Accessed 13 Sept 2017

8. Bundesnetzagentur $2017 \mathrm{https}$ //www.bundesnetzagentur.de/DE/Sachgebiete/ ElektrizitaetundGas/Unternehmen_Institutionen/Ausschreibungen/ Solaranlagen/BeendeteAusschreibungen/Ausschreibungen2017/ Ausschreibungen2017 node.html. Accessed 13 Sept 2017

\section{Submit your manuscript to a SpringerOpen ${ }^{\circ}$ journal and benefit from:}

- Convenient online submission

- Rigorous peer review

- Open access: articles freely available online

- High visibility within the field

Retaining the copyright to your article 